See discussions, stats, and author profiles for this publication at:

http://www.researchgate.net/publication/225339776

\title{
Litterfall deposition and leaf litter nutrient return in different locations at Northeastern Mexico. Plant Ecol
}

\author{
ARTICLE in PLANT ECOLOGY • OCTOBER 2011 \\ Impact Factor: 1.64 · DOI: 10.1007/s11258-011-9952-9
}

CITATIONS

8
DOWNLOADS

23
VIEWS

110

7 AUTHORS, INCLUDING:

\section{H. González-Rodríguez}

Autonomous University of Nuevo León 76 PUBLICATIONS 148 CITATIONS

SEE PROFILE

\section{Marco Vinicio Gómez-Meza}

Autonomous University of Nuevo León 43 PUBLICATIONS 108 CITATIONS

SEE PROFILE

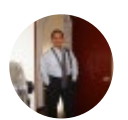

Tilo Gustavo Domínguez Gomez

Autonomous University of Nuevo León

28 PUBLICATIONS 11 CITATIONS

SEE PROFILE

Marisela Pando-Moreno

Autonomous University of Nuevo León

58 PUBLICATIONS 86 CITATIONS

SEE PROFILE 


\title{
Litterfall deposition and leaf litter nutrient return in different locations at Northeastern Mexico
}

\author{
H. González-Rodríguez • T. G. Domínguez-Gómez • \\ I. Cantú-Silva • M. V. Gómez-Meza • R. G. Ramírez-Lozano • \\ M. Pando-Moreno $\cdot$ C. J. Fernández
}

Received: 10 June 2009/Accepted: 26 February 2010/Published online: 19 August 2011

(C) Springer Science+Business Media B.V. 2011

\begin{abstract}
The aim of this study was to determine the litterfall production and macronutrient $(\mathrm{Ca}, \mathrm{K}$, $\mathrm{Mg}, \mathrm{N}$, and $\mathrm{P}$ ) deposition through leaf litter in four sites with different types of vegetation. Site one (Bosque Escuela) was located at $1600 \mathrm{~m}$ a.s.l. in a pine forest mixed with deciduous trees, second site (Crucitas at $550 \mathrm{~m}$ a.s.l.) in the ecotone of a Quercus spp. forest and the Tamaulipan thornscrub and third and fourth sites (Campus at $350 \mathrm{~m}$ a.s.l. and Cascajoso at $300 \mathrm{~m}$ a.s.l., respectively) were in the Tamaulipan thornscrub. Litter constituents (leaves, reproductive structures, twigs, and miscellaneous residues) were collected at 15-day intervals from December 21, 2006, throughout December 20, 2007. Collections were carried out in ten litter traps
\end{abstract}

H. González-Rodríguez ( $\varangle)$ · T. G. Domínguez-

Gómez · I. Cantú-Silva · M. Pando-Moreno

Facultad de Ciencias Forestales, Universidad Autónoma de Nuevo León, Apartado Postal 41, 67700 Linares, NL, Mexico

e-mail: humberto.gonzalezrd@uanl.edu.mx

\section{V. Gómez-Meza}

Facultad de Economía, Universidad Autónoma de Nuevo León, Monterrey, NL, Mexico

R. G. Ramírez-Lozano

Facultad de Ciencias Biológicas, Universidad Autónoma de Nuevo León, Monterrey, NL, Mexico

C. J. Fernández

Texas AgriLife Research and Extension Center at Corpus Christi, 10345 Agnes St., Corpus Christi, TX 78406, USA
$(1.0 \times 1.0 \mathrm{~m})$ randomly situated at each site of approximately $2,500 \mathrm{~m}^{2}$. Total annual litterfall deposition was 4407, 7397, 6304, and $6527 \mathrm{~kg} \mathrm{ha}^{-1} \mathrm{y}^{-1}$ for Bosque Escuela, Crucitas, Campus and Cascajoso, respectively. Of total annual litter production, leaves were higher varying from 74 (Bosque Escuela) to $86 \%$ (Cascajoso) followed by twigs from 4 (Cascajoso) to $14 \%$ (Crucitas), reproductive structures from 6 (Bosque Escuela) to 10\% (Crucitas), and miscellaneous litterfall from $<1$ (Campus) to $12 \%$ (Bosque Escuela). The $\mathrm{Ca}$ annual deposition was significantly higher in Cascajoso (232.7 kg ha $\mathrm{kg}^{-1}$ ), followed by Campus (182.3), Crucitas (130.5) and Bosque Escuela (30.3). The K $(37.5,32.5,24.8,7.2$, respectively), $\mathrm{Mg}(22.6,17.7,13.7,4.5$, respectively) followed the same pattern as $\mathrm{Ca}$. However, $\mathrm{N}$ was higher in Campus (85.8) followed by Crucitas (85.1), Cascajoso (68.3), and Bosque Escuela (18.3). The P was higher in Campus and Crucitas (4.0) followed by Cascajoso (3.4) and Bosque Escuela (1.4). On an annual basis for all sites, the order of nutrient deposition through leaf litter was $\mathrm{Ca}>\mathrm{N}>\mathrm{K}>$ $\mathrm{Mg}>\mathrm{P}$, whereas on site basis of total nutrient deposition $(\mathrm{Ca}+\mathrm{N}+\mathrm{K}+\mathrm{Mg}+\mathrm{P})$, the order was Cascajoso $>$ Campus $>$ Crucitas $>$ Bosque Escuela. $\mathrm{Ca}, \mathrm{K}, \mathrm{Mg}, \mathrm{N}$, and $\mathrm{P}$ nutrient use efficiency values in leaf litter were higher in Bosque Escuela, while lower figures were acquired in Cascajoso and Crucitas sites. It seems that the highest litterfall deposition was found in the ecotone of a Quercus spp. forest and the Tamaulipan thornscrub; however, the Tamaulipan 
thornscrub vegetation alone had better leaf litter nutrient return.

Keywords Litterfall production .

Litter components - Leaf litter nutrient return .

Tamaulipan thornscrub $\cdot$ Northeastern Mexico

\section{Introduction}

Litterfall and litter decomposition are key processes in nutrient cycling of forest ecosystems (Baker et al. 2001; Isaac and Nair 2006). In addition to these processes, throughfall and stemflow are the main sources to maintain soil fertility to the forest floor (Vasconcelos and Luizão 2004). Litterfall plays a fundamental role in nutrient turnover and in the transfer of energy between plants and soil, the main source of organic material and nutrients being accumulated in the uppermost layer of the soil. Nutrient release from decomposing litter is an important internal pathway for nutrient flux in forest ecosystems (Santa-Regina et al. 2005).

Evaluation of litterfall production is important for understanding nutrient cycling, forest growth, successional pathways, carbon fluxes, disturbance ecology, and interactions with environmental variables in forest ecosystems (Vasconcelos and Luizão 2004; Zhou et al. 2007). However, litterfall inputs vary widely among forest ecosystems in terms of quality (Duchesne et al. 2001; Vasconcelos and Luizão 2004) and quantity (Rothe and Binkley 2001; Zhou et al. 2007). The quality of soil organic matter is of great importance for the majority of the functional processes occurring in the soil of forest ecosystems (Santa-Regina et al. 2005). Despite the great number and well-documented floristic studies carried out at the Tamaulipan thornscrub or subtropical thornscrub woodlands, Northeastern Mexico, few studies have been carried out to address the spatial and temporal patterns of litterfall and nutrient deposition at different altitude gradients where plant species composition is different.

The nutrient cycling is of key importance in forest communities where sustainable litterfall production is an essential part of the aboveground net primary production and depends upon the nutritional status of soil, such as those found in the northeastern region of Mexico, whose vegetation depends on the biogeochemical cycles of plant nutrients contained in plant detritus (Vasconcelos and Luizão 2004). Therefore, this region provides an opportunity to investigate litterfall production and nutrient returns of forest and native vegetation in order to gain a better understanding of how to sustain and improve productivity in response to changes in resource availability. Thus, the aim of this study was to assess the annual cycle of litterfall production and nutrient deposition through leaf at different ecological sites in Northeastern Mexico.

\section{Materials and methods}

Study area

This study was carried out at four undisturbed sites located in the state of Nuevo Leon, Northeastern Mexico. Site one (Bosque Escuela) was located in a pine (Pinus pseudostrobus Lindl.) forest mixed with deciduous trees located in the Experimental Forest Research Station of the Universidad Autónoma de Nuevo León in the Sierra Madre Oriental Mountain, Iturbide county $\left(24^{\circ} 43^{\prime} \mathrm{N} ; 99^{\circ} 52^{\prime} \mathrm{W} ; 1600 \mathrm{~m}\right.$ a.s.l.). Mean annual air temperature is about $13.9^{\circ} \mathrm{C}$. Average annual rainfall is approximately $639 \mathrm{~mm}$. The soil of the site is mainly rocky and comprises upper cretaceous lutite or siltstone. Site two (Crucitas) was located in the ecotone of a Quercus sp. forest and the Tamaulipan thornscrub $\left(24^{\circ} 46^{\prime} \mathrm{N} ; 99^{\circ} 41^{\prime} \mathrm{W} ; 550 \mathrm{~m}\right.$ a.s.l.). Average total annual rainfall is $755 \mathrm{~mm}$ with an annual mean air temperature of $21^{\circ} \mathrm{C}$ (BravoGarza 1999). Site three (Campus) was located at the Experimental Research Station of the Faculty of Forest Sciences of University Autonomous of Nuevo León $\left(24^{\circ} 47^{\prime} \mathrm{N} ; 99^{\circ} 32^{\prime} \mathrm{W} ; 350 \mathrm{~m}\right.$ a.s.l.). The climate is subtropical and semiarid with warm summer. Monthly mean air temperature ranges from $14.7^{\circ} \mathrm{C}$ in January to $22.3^{\circ} \mathrm{C}$ in August, although daily high temperatures of $45^{\circ} \mathrm{C}$ are common during summer. Average total annual precipitation is about $805 \mathrm{~mm}$ with a bimodal distribution. The peak rainfall months are May, June, and September (González-Rodríguez et al. 2004). Site four (Cascajoso) was located in the Hacienda Guadalupe “Ejido" (24 $54^{\prime} \mathrm{N}$; 99 $32^{\prime} \mathrm{W}$; elevation, $300 \mathrm{~m}$ a.s.1.). Averaged annual temperature 
is $21^{\circ} \mathrm{C}$ with a mean maximum and mean minimum of 30 and $12^{\circ} \mathrm{C}$, respectively. Total cumulative annual rainfall is $672 \mathrm{~mm}$. Crucitas, Campus, and Cascajoso sites are located in Linares county. Vegetation of Campus and Cascajoso sites is known as the Tamaulipan thornscrub or subtropical thornscrub woodlands (SPP-INEGI 1986). In the last three sites, the dominant soils are deep, dark-gray, lime-gray, lime-clay Vertisols, with montmorillonite, which shrink and swell noticeably in response to changes in soil moisture content. Physical and chemical characteristics of the soils (four sites) at a profile depth of $0-20 \mathrm{~cm}$ are shown in Table 1 . In addition, registered mean monthly air temperatures $\left({ }^{\circ} \mathrm{C}\right)$ and cumulative monthly rainfall $(\mathrm{mm})$ are shown in Table 2.

\section{Collections of litterfall production}

At each site, ten litter traps $\left(1.0 \mathrm{~m}^{2}\right)$, made with wooden sides fitted with the nylon net bottom $(1 \mathrm{~mm}$ mesh size), randomly scattered over the entire area $\left(2,500 \mathrm{~m}^{2}\right)$ were used for litterfall collections. Each trap was placed approximately $0.30 \mathrm{~m}$ above the soil level to intercept litterfall. Trap contents were collected at 15-day intervals between December 21, 2006, and December 20, 2007. Since area and height above the ground of litter traps as well as the sampling period of collection in litterfall studies are variable, which in many circumstances depends on the total area sampled, type of vegetation, the temporal and spatial variation in litterfall production, and to prevent significant decomposition and leaching loss of nutrients by throughfall between collections resulting in an underestimation of the true litterfall flux of nutrients to the forest soil, in this study, the area of sampling, number of traps and height above soil level, and litter collection period are within the range of previous studies (Ukonmaanaho and Starr 2001; Finotti et al. 2003; Read and Lawrence 2003; Yang et al. 2004, 2006; Fang et al. 2007; Zhou et al. 2007). Litter contents were manually sorted into the following categories: leaves, reproductive structures (flowers, fruits, and seeds) twigs or branches $(<2 \mathrm{~cm}$ in diameter), and miscellaneous residues (unidentified, fine plant tissue such as bark, pieces of insect bodies or feces). Corrections were not accounted for weight sample losses from litter that might have decomposed between sampling dates or amount of litter blown into or out of traps by wind. Samples were oven-dried to a constant weight at $65^{\circ} \mathrm{C}$ for $72 \mathrm{~h}$ and weighed to the nearest milligram. In this study, the duration of the drying temperature is within the range of earlier reports (Vasconcelos and Luizão 2004; Zayed 2004; Pavón et al. 2005; Mlambo and Nyathi 2007; Zhou et al. 2007). Dry samples were ground in a Wiley mill (Thomas Scientific) to pass $1.0-\mathrm{mm}$ mesh sieve and were kept in closed paper envelopes.

\section{Chemical analyses}

By quintuplicate, leaf litter samples, in each trap, were subjected to mineral analysis. Mineral content
Table 1 Physical and chemical characteristics of soils (profile depth $0-20 \mathrm{~cm}$ ) at the studied sites in Northeastern Mexico

\begin{tabular}{lrrrr}
\hline Item & \multicolumn{2}{l}{ Sites } & & \\
\cline { 2 - 5 } & \multicolumn{1}{l}{ Bosque Escuela } & Crucitas & Campus & Cascajoso \\
\hline Sand $\left(\mathrm{g} \mathrm{kg}^{-1}\right)$ & 170.0 & 120.0 & 250.0 & 130.0 \\
Silt $\left(\mathrm{g} \mathrm{kg}^{-1}\right)$ & 430.0 & 420.0 & 500.0 & 610.0 \\
Clay $\left(\mathrm{g} \mathrm{kg}^{-1}\right)$ & 400.0 & 460.0 & 250.0 & 260.0 \\
Bulk density $\left(\mathrm{Mg} \mathrm{m}^{-3}\right)$ & 0.9 & 1.2 & 0.8 & 1.2 \\
Organic matter $(\%)$ & 6.0 & 4.0 & 7.0 & 2.0 \\
$\mathrm{pH}\left(\mathrm{CaCl}_{2} ; 0.01 \mathrm{M}\right)$ & 6.6 & 6.8 & 6.6 & 7.1 \\
$\mathrm{EC}\left(\mu \mathrm{S} \mathrm{cm}^{-1}\right)$ & 255.0 & 103.0 & 216.0 & 123.0 \\
$\mathrm{Ca}\left(\mathrm{mg} \mathrm{kg}^{-1}\right)$ & 8839.1 & 3063.5 & 8555.6 & 8000.2 \\
$\mathrm{~K}\left(\mathrm{mg} \mathrm{kg}^{-1}\right)$ & 297.4 & 310.4 & 109.5 & 134.7 \\
$\mathrm{Mg}\left(\mathrm{mg} \mathrm{kg}^{-1}\right)$ & 150.3 & 10.2 & 216.0 & 98.5 \\
$\mathrm{P}\left(\mathrm{mg} \mathrm{kg}^{-1}\right)$ & 5.1 & 3461.2 & 5604.6 & 1897.3 \\
$\mathrm{~N}\left(\mathrm{mg} \mathrm{kg}^{-1}\right)$ & 2957.3 & & & 5.2 \\
\hline
\end{tabular}


Table 2 Mean monthly air temperature $\left({ }^{\circ} \mathrm{C}\right)$ and cumulative monthly rainfall $(\mathrm{mm})$ at research sites in Northeastern Mexico

\begin{tabular}{|c|c|c|c|c|c|c|c|c|}
\hline \multirow[t]{3}{*}{ Month-year } & \multicolumn{8}{|l|}{ Sites } \\
\hline & \multicolumn{2}{|c|}{ Bosque Escuela } & \multicolumn{2}{|c|}{ Crucitas } & \multicolumn{2}{|c|}{ Campus } & \multicolumn{2}{|c|}{ Cascajoso } \\
\hline & ${ }^{\circ} \mathrm{C}$ & $\mathrm{mm}$ & ${ }^{\circ} \mathrm{C}$ & $\mathrm{mm}$ & ${ }^{\circ} \mathrm{C}$ & $\mathrm{mm}$ & ${ }^{\circ} \mathrm{C}$ & $\mathrm{mm}$ \\
\hline December 2006 & 10.8 & 24.2 & 14.7 & 26.4 & 15.1 & 32.2 & 16.0 & 6.6 \\
\hline January 2007 & 10.1 & 31.8 & 17.2 & 32.4 & 11.8 & 39.8 & 12.3 & 29.6 \\
\hline February 2007 & 12.4 & 10.0 & 19.5 & 64.8 & 16.2 & 64.2 & 17.1 & 22.0 \\
\hline March 2007 & 15.2 & 12.2 & 19.8 & 14.0 & 21.2 & 9.2 & 22.0 & 1.6 \\
\hline April 2007 & 17.0 & 19.6 & 20.6 & 52.6 & 21.8 & 30.8 & 23.8 & 49.8 \\
\hline May 2007 & 18.9 & 71.4 & 23.7 & 285.8 & 25.1 & 156.2 & 26.4 & 101.8 \\
\hline June 2007 & 20.6 & 109.4 & 25.5 & 127.8 & 26.8 & 86.8 & 28.3 & 24.4 \\
\hline July 2007 & 19.7 & 139.2 & 25.0 & 3.4 & 26.3 & 148.2 & 28.0 & 75.8 \\
\hline August 2007 & 19.4 & 179.2 & 25.6 & 118.2 & 26.7 & 159.2 & 28.3 & 73.2 \\
\hline September 2007 & 18.4 & 129.4 & 24.5 & 154.8 & 25.6 & 112.8 & 26.6 & 58.6 \\
\hline October 2007 & 16.4 & 31.8 & 22.0 & 35.2 & 23.0 & 19.2 & 23.8 & 15.6 \\
\hline November 2007 & 13.6 & 13.6 & 17.5 & 25.8 & 19.2 & 23.8 & 20.0 & 3.0 \\
\hline December 2007 & 13.6 & 2.4 & 16.2 & 0.8 & 17.3 & 0.6 & 18.3 & 1.6 \\
\hline Total annual & & 774.2 & & 942.0 & & 883.0 & & 463.6 \\
\hline
\end{tabular}

was estimated by incinerating samples in a muffle oven at $550^{\circ} \mathrm{C}$, during $5 \mathrm{~h}$. Ashes were digested in a solution containing $\mathrm{HCl}$ and $\mathrm{HNO}_{3}$, using the wet digestion technique (Cherney 2000). Concentrations of $\mathrm{Ca}$ (oxide nitrous/acetylene flame), $\mathrm{K}$, and $\mathrm{Mg}$ (air/acetylene flame) were determined by atomic absorption spectrophotometry (Varian, model SpectrAA-200), whereas $\mathrm{P}$ was quantified spectrophotometrically using a Perkin-Elmer spectrophotometer (Model Lamda 1A) at $880 \mathrm{~nm}$ (AOAC 1997). The Kjeldahl procedure was employed for total $\mathrm{N}$ analyses (AOAC 1997). Nutrient deposition at each site was calculated by multiplying leaves litter production by each sampling date by nutrient concentration for the same sampling date and site and adding them over the entire year. The accumulated values at each site were used as an estimate of the annual nutrient deposition. The leaf litter annual nutrient deposition values of $\mathrm{Ca}, \mathrm{K}, \mathrm{Mg}, \mathrm{P}$, and $\mathrm{N}$ were used to estimate within-site leaf litter nutrient use efficiency (LLNUE) defined as the ratio of annual leaf litter mass to annual leaf litter nutrient content deposition $\left(\mathrm{kg} \mathrm{ha}^{-1} \mathrm{y}^{-1}\right)$ (Vitousek 1982; Read and Lawrence 2003).

\section{Statistical analyses}

Litterfall deposition data, per sampling date, belonging to each litter constituent as well as leaf nutrient content data were subjected to one-way analysis of variance (Steel and Torrie 1980). Normal distribution and homogeneity of variances for each litter constituent and nutrient content data tested using the Kolmogorov-Smirnov, Shapiro-Wilk, and Levene tests (Brown and Forsythe 1974; Steel and Torrie 1980) indicated that litterfall and nutrient content data are non-normally distributed. Since for most sampling dates, ANOVA did not show the assumption of equality of variances, Kruskal-Wallis nonparametric test was employed (Ott 1993) to detect significant differences among sites at each sampling date. Hence, differences in litter deposition and nutrient content between sites were validated using the Mann-Whitney $U$ nonparametric test with the Bonferroni's correction method at $P=0.05$ (Wackerly et al. 2002). All applied statistical methods were according to the SPSS ${ }^{\circledR}$ (Statistical Package for the Social Sciences) software package (standard released version 13.0 for Windows, SPSS Inc., Chicago, IL).

\section{Results}

Litterfall deposition

Total litterfall deposition by site is shown in Fig. 1. In Bosque Escuela, it ranged from 3.6 to $42.4 \mathrm{~g} \mathrm{~m}^{-2}$; 
Fig. 1 Total litterfall deposition pattern at research sites. $P$-values of the Kruskal-Wallis test to detect significant differences among sites are shown at each sampling date within the graph. $P$-values $\leq 0.001$ are denoted as 0.001 .

Statistically significant probabilities $(P \leq 0.05)$ are shown in boldface. Bosque Escuela (filled diamond), Crucitas (filled square), Campus (filled triangle), Cascajoso (times symbol)
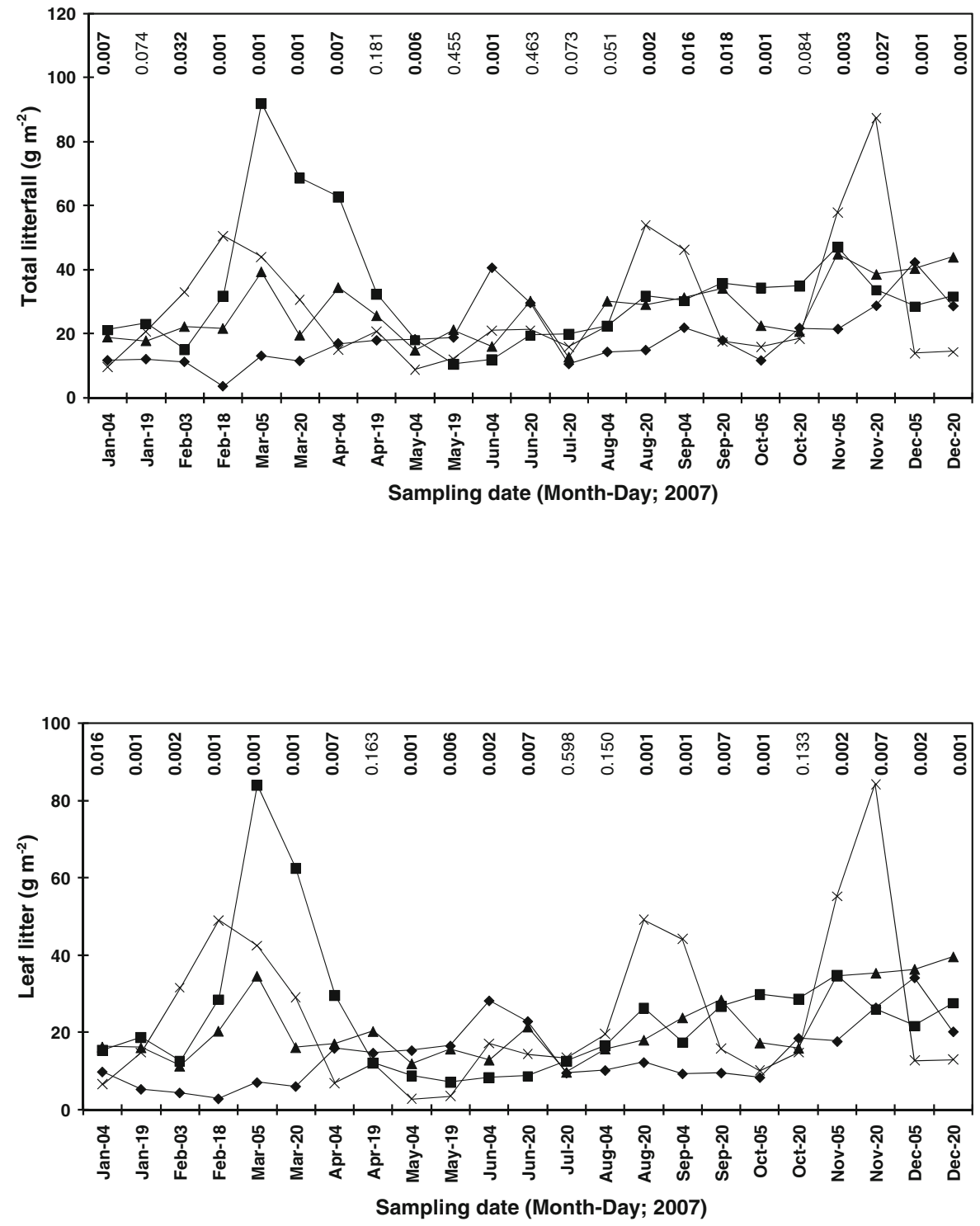

Sampling date (Month-Day; 2007)
Fig. 2 Leaf litterfall deposition pattern at research sites. $P$-values of the Kruskal-Wallis test to detect significant differences among sites are shown at each sampling date within the graph. $P$-values $\leq 0.001$ are denoted as 0.001 .

Statistically significant probabilities $(P \leq 0.05)$ are shown in boldface. Bosque Escuela (filled diamond), Crucitas (filled square), Campus (filled triangle), Cascajoso (times symbol) in Crucitas, from 10.6 to 91.9; in Campus, from 12.7 to 44.8; and in Cascajoso, from 8.8 to 87.6. Leaf litter deposition (Fig. 2) for Bosque Escuela varied from 2.9 to 34.2 ; for Crucitas, from 7.1 to 83.9; for Campus, from 9.8 to 39.5; and for Cascajoso, from 2.7 to 84.2 . The dynamics of reproductive structures litter inputs is shown in Fig. 3. Mean minimum reproductive structure deposition values for Bosque Escuela, Crucitas, Campus, and Cascajoso sites were $0.1,0.3,0.2$, and $0.2 \mathrm{~g} \mathrm{~m}^{-2}$, respectively, whereas maximum deposition was 5.4, 23.1, 10.3, and 7.3, respectively. The twig litter seasonal deposition (Fig. 4), mean minimum values ranged from 0.06
(Bosque Escuela) to $1.37 \mathrm{~g} \mathrm{~m}^{-2}$ (Crucitas), while mean maximum deposition values varied from 4.08 (Cascajoso) to $14.23 \mathrm{~g} \mathrm{~m}^{-2}$ (Crucitas). The Fig. 5 shows the seasonal trend of miscellaneous litter deposition, which illustrates that the minimum and maximum observed values ranged from 0.0 (Campus) to $7.0 \mathrm{~g} \mathrm{~m}^{-2}$ (Bosque Escuela).

Total annual litter production and its components (leaves, reproductive structures, twigs, and miscellaneous) are shown in Table 3. Crucitas site showed the highest values followed by Cascajoso, Campus, and Bosque Escuela. Leaves represented the main component with a deposition that ranged from 74 (Bosque 


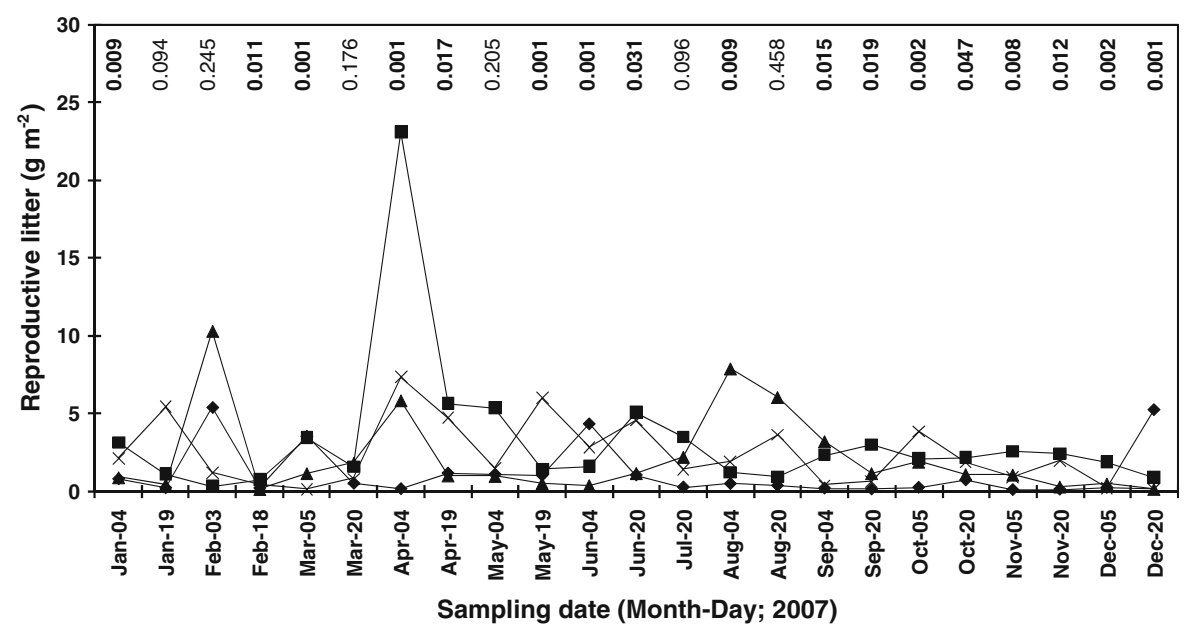

Fig. 3 Reproductive litterfall deposition pattern at research sites. $P$-values of the Kruskal-Wallis test to detect significant differences among sites are shown at each sampling date within the graph. $P$-values $\leq 0.001$ are denoted as 0.001 . Statistically significant probabilities $(P \leq 0.05)$ are shown in boldface. Bosque Escuela (filled diamond), Crucitas (filled square), Campus (filled triangle), Cascajoso (times symbol)
Fig. 4 Twig litterfall deposition pattern at research sites. $P$-values of the Kruskal-Wallis test to detect significant differences among sites are shown at each sampling date within the graph. $P$-values $\leq 0.001$ are denoted as 0.001 .

Statistically significant probabilities $(P \leq 0.05)$ are shown in boldface. Bosque Escuela (filled diamond), Crucitas (filled square), Campus (filled triangle), Cascajoso (times symbol)

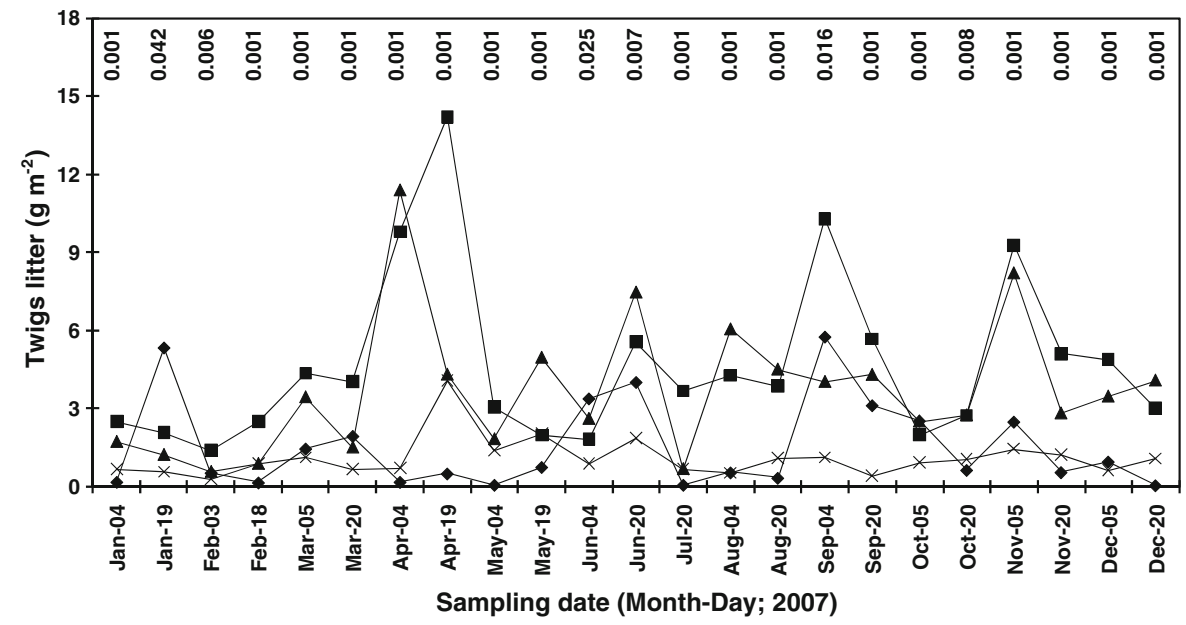

from 33.1 to 48.5. Leaf litter K content (Fig. 6b) for Bosque Escuela varied from 1.1 to $4.2 \mathrm{mg} \mathrm{gdw}^{-1}$; for Crucitas, from 1.8 to 9.1; for Campus, from 2.5 to 11.0; and for Cascajoso, from 1.9 to 13.4. As a general seasonal trend, Bosque Escuela, Crucitas, Campus, and Cascajoso acquired an average $\mathrm{Mg}$ content of about $1.4,2.4,3.5$, and $4.0 \mathrm{mg} \mathrm{gdw}^{-1}$, respectively, during the experimental period (Fig. 6c). Averaged monthly leaf litter P content for Bosque Escuela, Crucitas, Campus, and Cascajoso were $0.4,0.8,0.8$, and $0.7 \mathrm{mg} \mathrm{gdw}^{-1}$, respectively (Fig. 6d). The N content (Fig. 6e) in Bosque Escuela varied from 3.9 to $7.6 \mathrm{mg} \mathrm{gdw}^{-1}$; in Crucitas, from 
Fig. 5 Miscellaneous litterfall deposition pattern at research sites. $P$-values of the Kruskal-Wallis test to detect significant differences among sites are shown at each sampling date within the graph. $P$-values $\leq 0.001$ are denoted as 0.001 .

Statistically significant probabilities $(P \leq 0.05)$ are shown in boldface. Bosque Escuela (filled diamond), Crucitas (filled square), Campus (filled triangle), Cascajoso (times symbol)

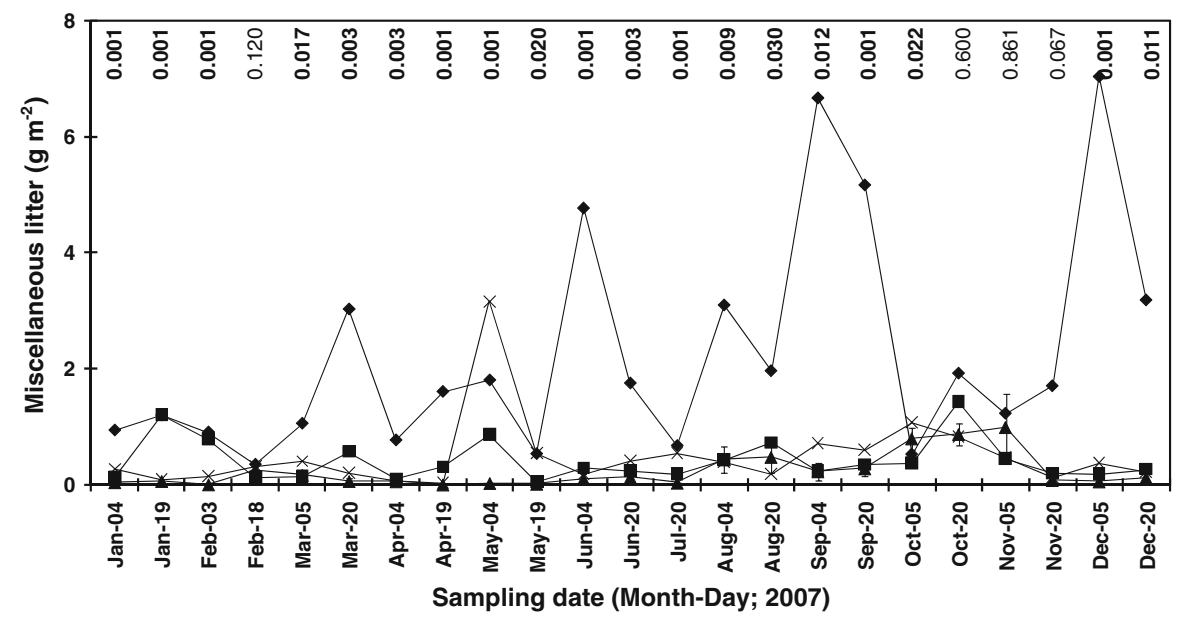

Table 3 Annual means of litter and leaf litter nutrient depositions and LLNUE at research sites in Northeastern Mexico

Leaf litter nutrient use efficiency ( $L L N U E)$ was calculated as ( $\mathrm{kg}$ leaf litter $\left.\mathrm{ha}^{-1} \mathrm{y}^{-1}\right) /(\mathrm{kg}$ leaf litter nutrient $\mathrm{ha}^{-1} \mathrm{y}^{-1}$ )

\begin{tabular}{lrrrr}
\hline Deposition features & \multicolumn{3}{l}{ Sites } & \\
\cline { 2 - 5 } & Bosque Escuela & Crucitas & Campus & Cascajoso \\
\hline Total $\left(\mathrm{kg} \mathrm{ha}^{-1} \mathrm{y}^{-1}\right)$ & 4407.3 & 7397.1 & 6304.1 & 6527.2 \\
Leaves & 3254.0 & 5560.5 & 4892.0 & 5612.6 \\
Reproductive & 277.8 & 700.9 & 504.2 & 545.5 \\
Twigs & 356.3 & 1041.1 & 855.5 & 255.5 \\
Miscellaneous & 519.2 & 94.5 & 52.3 & 113.5 \\
Ca & 30.3 & 130.5 & 182.3 & 232.7 \\
$\mathrm{~K}$ & 7.2 & 24.8 & 32.5 & 37.5 \\
$\mathrm{Mg}$ & 4.5 & 13.7 & 17.7 & 22.6 \\
$\mathrm{P}$ & 1.4 & 4.0 & 4.0 & 3.4 \\
$\mathrm{~N}$ & 18.3 & 85.1 & 85.8 & 68.3 \\
$\mathrm{LLNUE}$ & & & & \\
$\mathrm{Ca}$ & 107.4 & 42.6 & 26.8 & 24.1 \\
$\mathrm{~K}$ & 451.9 & 224.2 & 150.5 & 149.7 \\
$\mathrm{Mg}$ & 723.1 & 405.9 & 276.4 & 248.3 \\
$\mathrm{P}$ & 2324.3 & 1390.1 & 1223.0 & 1650.8 \\
$\mathrm{~N}$ & 177.8 & 65.3 & 57.0 & 82.2 \\
\hline
\end{tabular}

12.5 to $20.2 \mathrm{mg} \mathrm{gdw}^{-1}$; in Campus, from 16.1 to 20.4; and in Cascajoso, from 8.5 to 16.3 .

The $\mathrm{Ca}$ annual deposition was higher in Cascajoso followed by Campus, Crucitas, and Bosque Escuela. The $\mathrm{K}$ and $\mathrm{Mg}$ followed the same pattern as $\mathrm{Ca}$. However, $\mathrm{N}$ was higher in Campus followed by Crucitas, Cascajoso, and Bosque Escuela. The P was similar in Campus and Crucitas and both were higher than Cascajoso and Bosque Escuela (Table 3). Regardless of site, the annual nutrient inputs through leaf litter exhibited the following rank order: $\mathrm{Ca}>\mathrm{N}>\mathrm{K}>\mathrm{Mg}>\mathrm{P}$ (Table 3). Total annual nutrient deposition $(\mathrm{Ca}+\mathrm{K}+\mathrm{Mg}+\mathrm{P}+\mathrm{N})$ for Bosque Escuela, Crucitas, Campus, and Cascajoso was $61.7,258.1,322.3$, and $364.5 \mathrm{~kg} \mathrm{ha}^{-1} \mathrm{y}^{-1}$, respectively. 

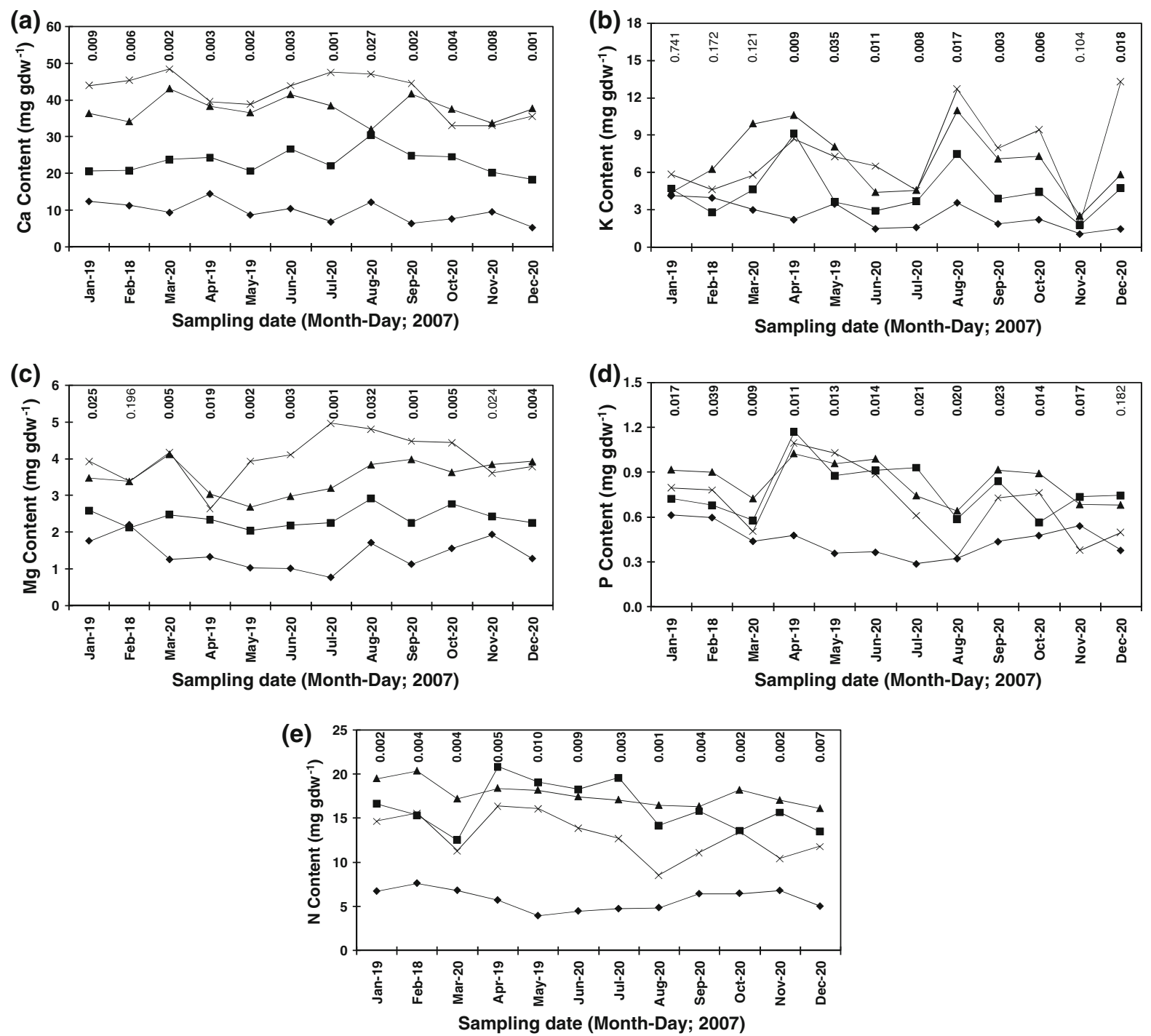

Fig. 6 Monthly variations of $\mathrm{Ca}, \mathrm{K}, \mathrm{Mg}, \mathrm{P}$, and $\mathrm{N}$ contents in leaf litter at research sites. $P$-values of the Kruskal-Wallis test to detect significant differences among sites are shown at each sampling date within the graph. $P$-values $\leq 0.001$ are denoted

Leaf litter nutrient use efficiency for $\mathrm{Ca}, \mathrm{K}$, and $\mathrm{Mg}$ exhibited the following rank order: Bosque Escuela $>$ Crucitas $>$ Campus $\geq$ Cascajoso; meanwhile, the $\mathrm{P}$ and $\mathrm{N}$ trend order was Bosque Escuela $>$ Cascajoso $>$ Crucitas $\geq$ Campus

(Table 3). Calcium LLNUE ranged from 24 (Cascajoso) to 107 (Bosque Escuela), K from 150 (Campus and Cascajoso) to 451 (Bosque Escuela), $\mathrm{Mg}$ from 248 (Cascajoso) to 723 (Bosque Escuela), P from 1,223 (Campus) to 2,324 (Bosque Escuela), and $\mathrm{N}$ from 57 (Campus) to 178 (Bosque Escuela). as 0.001 . Statistically significant probabilities $(P \leq 0.05)$ are shown in boldface. Bosque Escuela (filled diamond), Crucitas (filled square), Campus (filled triangle), Cascajoso (times symbol)

\section{Discussion}

It appears that litterfall and its constituents (leaves, reproductive structures, twigs, and miscellaneous) and nutrient $(\mathrm{Ca}, \mathrm{K}, \mathrm{Mg}, \mathrm{P}$, and $\mathrm{N}$ ) deposition through leaf litter significantly differed quantitatively and qualitatively on a seasonal and annual basis among research sites. In addition, these differences could be extended to the LLNUE estimated for each site. It has been reported that litter production and litter chemistry in forest ecosystems is determined by age and rainfall 
(Lawrence 2005), species composition (Pavón et al. 2005; Sariyildiz and Anderson 2005), soil and nutrient availability (Read and Lawrence 2003; Vasconcelos and Luizão 2004; Dent et al. 2006), stand structure (Yang et al. 2006; Zhou et al. 2007), and successional stage (Yankelevich et al. 2006). In addition, rates of nutrient return to the forest soil are controlled not only by the amount of litter production but also by the nutrient concentrations in litter components (Yang et al. 2006; Mlambo and Nyathi 2007). Since at the research sites, there are not conclusive studies related to global warming and long-term tendencies, in this study, the significant seasonal differences in biomass production might have been related, to some extent, to concurrent seasonal extreme environmental conditions such as droughts and frosts, which are typical in the northeastern region of Mexico (González-Rodríguez et al. 2000, González-Rodríguez et al. 2004, 2007) and or changes in phenological events such as leaf abscission and shedding, shoot initiation, flowering, and fruiting (Palma et al. 2000). Previous findings in Northeastern Mexico (González-Rodríguez et al. 2007) have revealed that during wet months (August and September) when rainfall was heavy, branches and fruits were the main litter constituents, whereas in the dry and winter months, there was a greater contribution of leaves due to drought and freezing temperatures.

Even though, in this study, litterfall deposition occurred throughout the experimental period, there were significant main seasonal peaks for the different litter components in relation to input quantity, variability, and order of magnitude (Figs. 2, 3, 4, 5 ). This litter production varied regardless of total or individual litter components studied at each site. In addition, since leaf litterfall significantly differed within and between sites and sampling dates, seasonal leaf litter nutrient peaks were also registered for elements such as $\mathrm{K}$ and $\mathrm{P}$, while $\mathrm{Ca}, \mathrm{Mg}$, and $\mathrm{N}$ showed a relatively constant content throughout the year (Fig. 6a-e). In fact, $\mathrm{Ca}, \mathrm{K}, \mathrm{Mg}, \mathrm{P}$, and $\mathrm{N}$ in Bosque Escuela, and $\mathrm{Ca}$ and $\mathrm{Mg}$ at Crucitas leaf litter nutrient content remained fairly steady and lower throughout the year. Thus, leaf litter was the primary source of nutrients and consequently determined to some extent the seasonal peaks of nutrient deposition as has been previously documented (Callaway and Nadkarni 1991). Although in this study nutrient content and deposition was not measured in other litter constituents such as twigs or reproductive structures, other studies have shown that nutrient concentrations were higher in leaf litter than other litter components (Yang et al. 2006).

Foliar nutrient movements from senescing leaves to active plant tissues or woody structures have been considered as a physiological mechanism of nutrient cycling since it plays a major role in nutrient conservation by deciduous tree species because nutrients following this pathway are not lost through litterfall (Duchesne et al. 2001). In this regard, it can be suggested that woody plant species from Bosque Escuela (70\% hard woody-deciduous) could be more efficient in nutrient transfers than plant species from the other sites, since annual deposition levels of $\mathrm{Ca}, \mathrm{K}$, and $\mathrm{Mg}$ observed in leaf litter from Bosque Escuela were lower compared with Crucitas, Campus, or Cascajoso (Fig. 6a-c). This suggestion is supported by the high nutrient use efficiency, observed in Bosque Escuela with respect to other three sites (Table 3), in order to minimize nutrient losses; however, this statement has to be taken cautiously since seasonal determinations of nutrients in active foliar tissue and leaching (e.g., dry and or throughfall) deposition were not quantified in this study. The lower leaf P levels throughout the year observed in Bosque Escuela (Fig. 6d) compared to Crucitas, Campus, or Cascajoso as well as its achieved marginal annual deposition through leaf litter (Table 3) compared with $\mathrm{Ca}, \mathrm{K}, \mathrm{Mg}$, and $\mathrm{N}$ suggest that this nutrient is available at very low levels in the soil solution or rather; it is easily retranslocated from leaf tissue to stems, branches, or other plant structures. Thus, further measurements are required to accurately estimate $\mathrm{P}$ nutrient resorption pools as has been previously pointed out (Duchesne et al. 2001; Read and Lawrence 2003; Dent et al. 2006). Conversely, the low levels of $\mathrm{N}$ deposition in Bosque Escuela compared with Crucitas, Campus, or Cascajoso could be associated with the capability of symbiotic nitrogen fixation potential of Fabaceae plant species observed at research sites (Zitzer et al. 1996), since at Bosque Escuela, plant species belonging to the Fabaceae family represented only $4 \%$ of total species richness in the experimental plot, while in Crucitas, Campus, and Cascajoso, this taxonomic proportion reached values of about 20,25, and $12 \%$, respectively. Thus, it seems that $\mathrm{N}$ nutrient use efficiency in leaf litter showed an inverse relationship with the proportion of Fabaceae plant species. In addition, it has been proposed that tree species on fertile soils tend to 
produce leaves and leaf litters with high nitrogen content, which in turn decompose rapidly and support high plant production through fast turnover of the nutrient pools (Sariyildiz and Anderson 2005). Furthermore, Forrester et al. (2005) and Rothe and Binkley (2001) argued that mixed forests stands containing $\mathrm{N}$-fixing species increase and improve nutrient cycling through litterfall when compared with monoculture or stands containing fewer $\mathrm{N}$-fixing species.

However, Read and Lawrence (2003) proposed that nutrient limitation in the dry tropics is related to water deficits since dry conditions prevent nutrient absorption from soil and consequently affect the release and mineralization of nutrients by slowing decomposition. Dent et al. (2006) have also suggested that the quantity and nutrient content of small litter decreased along a gradient of soil nutrient availability from alluvial forest (fertile soil) through sandstone forest (least fertile).

On an annual basis, the contribution of leaves, reproductive structures, twigs, and miscellaneous to total litterfall deposition in Campus and Cascajoso sites are within the range of previously documented studies (González-Rodríguez et al. 2007) in the subtropical woodlands of Northeastern Mexico. However, observed differences in leaf fall in Crucitas, Campus, and Cascajoso compared to Bosque Escuela could be related to the continuous shedding of leaves of deciduous plant species, which is a characteristic of the Tamaulipan thornscrub ecosystem, as a morphological and physiological mechanism to cope with water deficits and high temperatures to avoid plant tissue dehydration and water lost through transpirational flux (Stienen et al. 1989; González-Rodríguez et al. 2004).

\section{Implications}

The statistical analysis indicated that more sampling dates were significant for total annual litter and its constituents (leaves, reproductive structures, twigs, and miscellaneous residues) than for macronutrient (Ca, $\mathrm{K}, \mathrm{Mg}, \mathrm{N}$, and $\mathrm{P}$ ) deposition of leaf litter. Therefore, there is a relative homogeneity among sites with respect to the amount of macronutrients, particularly $\mathrm{P}$ and $\mathrm{K}$ contents, where the $P$-values $>0.001$ for the 13 sampling dates are considered. In general, the statistical differences found by sites were not systematically associated with specific sampling dates or related to special behavior of sites. In addition, site one (Bosque Escuela) provided relatively low means for almost all the studied variables. Thus, results of this study suggest the importance of litterfall production not only in terms of nutrient cycling to the forest soil in different stand communities but also to maintain fundamental ecological and ecosystem processes such as soil formation, prevent soil erosion, maintain soil fertility and substrates for plant and microbial species, support and sustain life for invertebrate fauna, increase organic matter mineralization, improve soil physical and chemical properties such as soil water availability and infiltration to enhance nutrient absorption, plant regeneration and establishment, and root growth; all of these are interrelated and integrated to sustain and maintain ecosystem productivity and biodiversity. Moreover, results of the present study could be used to implement site-specific management practices. Furthermore, although this type of investigations date back since more than 100 years, to some extent, the present work, as far as is known to the authors, could be considered as one of the main and basic studies carried out in the Northeastern ecosystems of Mexico, which provides and opens new research horizons and opportunities to understand nutrient cycling in forests soils. Further research projects could be suggested in order to explain how litter constituent decomposition processes are affected by their own chemistry composition, physicochemical environmental variables, soil properties, microbial communities and consequently elucidate nutritional fluxes.

Acknowledgments Valuable technical assistance provided by Elsa Dolores González Serna and Manuel Hernández Charles is gratefully recognized. The authors appreciate and wish to thank too the land owners of the Crucitas and Cascajoso sites for providing the facilities to establish the experimental sites. This research was funded in part by Universidad Autónoma de Nuevo Leon (PAICYT grants CN905-04 and CN133-05) and Consejo Nacional de Ciencia y Tecnología (CONACYT, grant P-52666533). Useful suggestions from two anonymous reviewers helped to improve the manuscript.

\section{References}

AOAC (1997) Official methods of analysis, 16th edn. Association of Official Analytical Chemists, Washington, DC

Baker TT III, Lockaby BG, Conner WH, Meier CE, Stanturf JA, Burke MK (2001) Leaf litter decomposition and nutrient dynamics in four southern forested floodplain communities. Soil Sci Soc Am 65:1334-1347 
Bravo-Garza MR (1999) Distribución de la materia orgánica del suelo en ecosistemas naturales e inducidos en el Estado de Nuevo León. Tesis de Licenciatura. Facultad de Ciencias Forestales, UANL, Linares, p 84

Brown MB, Forsythe AB (1974) Robust tests for the equality of variances. J Am Stat Ass 69:364-367

Callaway RM, Nadkarni NM (1991) Seasonal patterns of nutrient deposition in a Quercus douglasii woodland in central California. Plant Soil 137:209-222

Cherney DJR (2000) Characterization of forages by chemical analysis. In: Givens DI, Owen E, Axford RFE, Omed HM (eds) Forage evaluation in ruminant nutrition. CAB International, Wallingford, pp 281-300

Dent DH, Bagchi R, Robinson DR, Majalap-Lee N, Burslem DFRP (2006) Nutrient fluxes via litterfall and leaf litter decomposition vary across a gradient of soil nutrient supply in a lowland tropical rain forest. Plant Soil 288:197-215

Duchesne L, Ouimet R, Camiré C, Houle D (2001) Seasonal nutrient transfers by foliar resorption, leaching, and litter fall in a northern hardwood forest at Lake Clair watershed, Quebec, Canada. Can J For Res 31:334-344

Fang JY, Liu GH, Zhu B, Wang XK, Liu SH (2007) Carbon budgets of three temperate forest ecosystems in Dongling Mt., Beijing, China. Sci China Ser D-Earth Sci 50:92-101

Finotti R, Freitas SR, Cerqueira R, Vieira MV (2003) A method to determine the minimum number of litter traps in litterfall studies. Biotropica 35:419-421

Forrester DI, Bauhus J, Cowie AL (2005) Nutrient cycling in a mixed-species plantation of Eucalyptus globulus and Acacia mearnsii. Can J For Res 35:2942-2950

González-Rodríguez H, Cantú-Silva I, Gómez-Meza MV, Jordan WR (2000) Seasonal plant water relationships in Acacia berlandieri. Arid Soil Res Rehabil 14:343-357

González-Rodríguez H, Cantú-Silva I, Gómez-Meza MV, Ramírez-Lozano RG (2004) Plant water relations of thornscrub shrub species, Northeastern Mexico. J Arid Environ 58:483-503

González-Rodríguez H, Cantú-Silva I, Ramírez-Lozano RG, Gómez-Meza MV (2007) Litterfall deposition in subtropical woodlands, Northeastern Mexico. Proceedings of the Deutscher Tropentag 2007, October 9-11, 2007, Witzenhausen, Germany, pp 1-10

Isaac SR, Nair MA (2006) Litter dynamics of six multipurpose trees in a homegarden in Southern Kerala, India. Agro Syst 67:203-213

Lawrence D (2005) Regional-scale variation in litter production and seasonality in tropical dry forests of Southern Mexico. Biotropica 37:561-570

Mlambo D, Nyathi P (2007) Litterfall and nutrient return in a semi-arid Southern African savanna woodland dominated by Colophospermum mopane. Plant Ecol 196:101-110

Ott L (1993) An introduction to statistical methods and data analysis, 2nd edn. Duxbury Press, Boston, p 775

Palma RM, Defrieri RL, Tortarolo MF, Prause J, Gallardo JF (2000) Seasonal changes of bioelements in the litter and their potential return to green leaves in tour species of the Argentine subtropical forest. Ann Bot 85:181-186
Pavón HN, Briones VO, Flores RJ (2005) Litterfall production and nitrogen content in an intertropical semi-arid Mexican scrub. J Arid Environ 60:1-13

Read L, Lawrence D (2003) Litter nutrient dynamics during succession in dry tropical forests of the Yucatan: regional and seasonal effects. Ecosystems 6:747-761

Rothe A, Binkley D (2001) Nutritional interactions in mixed species forests: a synthesis. Can J For Res 31:1855-1870

Santa-Regina J, Salazar S, Leonardi S, Rapp M (2005) Nutrient pools to the soil through organic matter in several Castanea sativa Mill. coppices of Mountainous Mediterranean climate areas. Acta Hort 693:341-348

Sariyildiz T, Anderson JM (2005) Variation in the chemical composition of green leaves and leaf litters from three deciduous tree species growing on different soil types. For Ecol Manage 210:303-319

SPP-INEGI (1986) Síntesis geográfica del estado de Nuevo León. Secretaría de Programación, y Presupuesto. Instituto Nacional de Geografía e Informática, México

Steel RGD, Torrie JH (1980) Principles and procedures of statistics. A biometrical approach, 2nd edn, 632 p. McGraw-Hill Book Company, New York

Stienen H, Smits MP, Reid N, Landa J, Boerboom JHA (1989) Ecophysiology of 8 woody multipurpose species from semiarid Northeastern Mexico. Ann Sci Fost 46:454-458

Ukonmaanaho L, Starr M (2001) The importance of leaching from litter collected in litterfall traps. Env Moni Assess 66:129-146

Vasconcelos HL, Luizão FJ (2004) Litter production and litter nutrient concentrations in a fragmented Amazonian Landscape. Ecol Appl 14:884-892

Vitousek P (1982) Nutrient cycling and nutrient use efficiency. Am Nat 119:553-572

Wackerly DD, Mendenhall W, Scheaffer RL (2002) Estadística matemática con aplicaciones. 6ta edición. Editorial Thomson International, México, p 872

Yang YS, Guo JF, Chen GS, Xie JS, Cai LP, Lin P (2004) Litterfall, nutrient return, and leaf-litter decomposition in four plantations compared with a natural forest in subtropical China. Ann For Sci 61:465-476

Yang W-Q, Wang K-Y, Kellomäki S, Zhang J (2006) Annual and monthly variations in litter macronutrients of three subalpine forests in Western China. Pedosphere 16:788-798

Yankelevich SN, Fragoso C, Newton AC, Russell G, Heal OW (2006) Spatial patchiness of litter, nutrients and macroinvertebrates during secondary succession in a tropical montane cloud forest in Mexico. Plant Soil 286:123-139

Zayed MA (2004) Litter fall, nitrogen and phosphorus reabsorption in Zygophyllum album (Zygophyllaceae) in the Mediterranean coastal region and in Suez desert region. Acta Bot Hung 46:235-242

Zhou G, Guan L, Wei X, Zhang D, Zhang Q, Yan J, Wen D, Liu J, Liu S, Huang Z, Kong G, Mo J, Yu A (2007) Litterfall production along successional and altitudinal gradients of subtropical monsoon evergreen broadleaved forests in Guangdong, China. Plant Ecol 188:77-89

Zitzer SF, Archer SR, Boutton TW (1996) Spatial variability in the potential for symbiotic $\mathrm{N}_{2}$ fixation by woody plants in a subtropical savanna ecosystem. J Appl Ecol 33:1125-1136 